\title{
ANEMIA APLASTICĂ - ASPECTE TERAPEUTICE ŞI DEONTOLOGICE
}

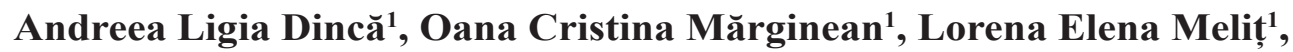 \\ Raluca Damian², Mihaela Chinceşan ${ }^{1}$

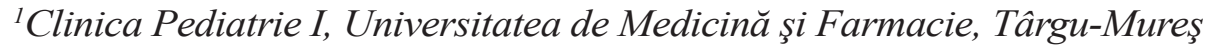 \\ ${ }^{2}$ Clinica de Neonatologie l, Spitalul Județean de Urgență, Târgu-Mureş
}

\begin{abstract}
REZUMAT
Anemia aplastică este o patologie hematologică severă, potențial fatală, caracterizată prin citopenie periferică şi măduvă osoasă hipocelulară, cu o prevalență de 2-6 cazuri la 1 milion locuitori. Prezentarea actuală ilustrează cazul unui copil de 9 ani, fără antecedente personale patologice cunoscute, şi cu debut brusc, aparent în plină stare de sănătate, diagnosticat cu anemie aplastică idiopatică severă şi cu evoluție fulminantă. Lipsa de complianță a părinților la actul medical, precum şi lipsa unei legislații care să protejeze copilul, au dus la decesul pacientului într-un interval foarte scurt de timp.
\end{abstract}

Cuvinte cheie: copil, pancitopenie, anemie aplastică

\section{INTRODUCERE}

Anemia aplastică este o disfuncție hematologică severă, potențial letală, caracterizată printr-o măduvă osoasă hipo/aplastică şi pancitopenie periferică, fiind o boală rară, cu apariție sporadică, necontagioasă, cauzată de distrugerea celulei stem pluripotente în măduvă şi poate duce la insuficiență medulară (1).

Anemia aplastică poate fi dobândită sau congenitală. Tipul congenital este rar şi de obicei asociat cu anemie Fanconi sau diskeratoză congenitală. Forma dobândită (peste $80 \%$ din cazuri) poate fi cauzată de mai mulți potențiali triggeri: boli autoimune, expunere la factori externi/de mediu; administrarea de preparate farmaceutice (Cloramfenicol!), infecții virale (parvovirusuri), mycobacterii; carențe severe (vit. B, folați), hemoglobinuria paroxistică nocturnă, transplant hepatic ortotopic pentru hepatitele fulminante (3), sarcina; sau, $>50 \%$ din cazuri, idiopatică $(2,3,4)$. Cea mai des acceptată ipoteză este totuşi cea autoimună; boala pare a fi secundară distrucției imunologice a celulei hematopoietice (5-7).
Simptomatologia bolii se referă la efectele insuficienței medulare: anemie marcată, sângerări, infecții. Există semne care pot sugera un sindrom de insuficiență medulară moştenită precum: pigmentare tegumentară anormală, statură mică, disfuncții organice, microcefalie, hipogonadism, anomalii scheletale $(8,9)$.

Diagnosticul pozitiv se pune pe baza examinărilor paraclinice hematologice. Mai multe hemoleucograme care pun în evidență pancitopenie sugerează diagnosticul, însă doar biopsia medulară pune diagnosticul de certitudine. Anemia aplastică severă este o urgență hematologică, măsurile terapeutice trebuie instituite cât mai prompt. Complianţa pacientului la terapie este foarte importantă pentru prognosticul imediat şi pe termen lung. Alternativele de tratament pot fi strict farmacologice, cu agenți imunosupresori, antiglobulina antitimocitară, factori de stimulare hematopoietică, antimetaboliți, agenți chelatori; sau non-farmacologice: măsuri de terapie intensivă, transfuzii de preparate sanguine, transplantul de măduvă osoasă. În situații foarte grave, recomandarea este transplantul de măduvă de urgență; acesta este de cele mai multe ori curativ, 
însă este condiționat de oportunitatea găsirii unui donator compatibil (ideal un frate sau o soră). Rata de supraviețuire este de $68 \%$ la 10 ani la pacienții care au primit doar imunosupresoare, față de $73 \%$ la pacienții la care s-a efectuat transplant de celule stem. În cazul terapiei imunosupresoare s-a observat totuşi o rată de recidivă mai mare, precum şi apariția pe termen lung a altor patologii clonale. $(10,11)$

\section{PREZENTARE DE CAZ}

Prezentăm cazul unui pacient de sex masculin, în vârstă de 9 ani care a fost transferat de la nivel teritorial în Clinica Pediatrie I Târgu-Mureş, Compartimentul Hemato-Oncologie, acuzând o stare generală alterată, paloare mucotegumentară, somnolență marcată şi sângerări spontane la nivelul cavităţii bucale. Mama a relatat debutul bolii actuale cu aproximativ 4 zile anterior prezentării, afirmativ în urma unui traumatism prin cădere. Antecedentele heredo-colaterale şi personale patologice ale copilului au fost nesemnificative.

La internare, a prezentat stare generală influențată, afebrilitate, constituție hipostenică, Greutate: 23 kg- $\mathrm{P}_{10}$; Înălțime: $130 \mathrm{~cm}-\mathrm{P}_{50}$, facies suferind, paloare mucotegumentară marcată, peteşii şi echimoze pe trunchi şi membre, torace astenic, tahicardie (AV: 130 bpm), sângerări gingivale spontane, hematoame gingivale, ficat la $2 \mathrm{~cm}$ sub rebordul costal drept, hematom scrotal, fără semne de iritație meningeană. Hemoleucograma a evidențiat o pancitopenie severă cu Hematii: $0,81 \mathrm{mil} / \mathrm{uL}$, Hemoglobină: 2,4 g/dL, Hematocrit: $6,7 \%$, Volum eritrocitar mediu: 82,7fL; Leucocite: 1.300/uL, Neutrofile: 500/uL, Limfocite: 700/uL, Trombocite: < 1.000/uL; Reticulocite: $0,2 \%$; Frotiu periferic cu hipocelularitate; VSH: 43 mm/h, Feritina: 681,9 ng/mL, Fosfataza alcalină: $88 \mathrm{U} / \mathrm{L}$; restul analizelor au fost în parametri normali. Medulograma: Mielocit: 1\%, Metamielocit: $1 \%$, Nesegmentate: $2 \%$, Segmentate: $6 \%$, Eozinofile: $2 \%$, Bazofile: $1 \%$, Limfocite mici: $79 \%$, Monocite: $1 \%$. Eritroblaşti policromatofili: 3\%, Eritroblaşti oxifili: 3\%, Plasmocite: 1\%, Mastocite: $1 / 100$; preparat cu celularitate foarte scăzută. Hipocelularitate a măduvei osoase (Fig. 1).

Serologia TORCH a fost negativă, cu excepția IgG anti-CMV şi IgG anti-HSV care au fost pozitive. Ecografie abdominală a evidențiat hepatomegalie uşoară. Radiografia toracică nu a identificat elemente patologice. Fundul de ochi a evidențiat hemoragii masive retiniene, parapapilare, ambii ochi. Tomografia craniană a fost negativă, iar ecocardiografia a arătat o minimă lamă de lichid în pericard.

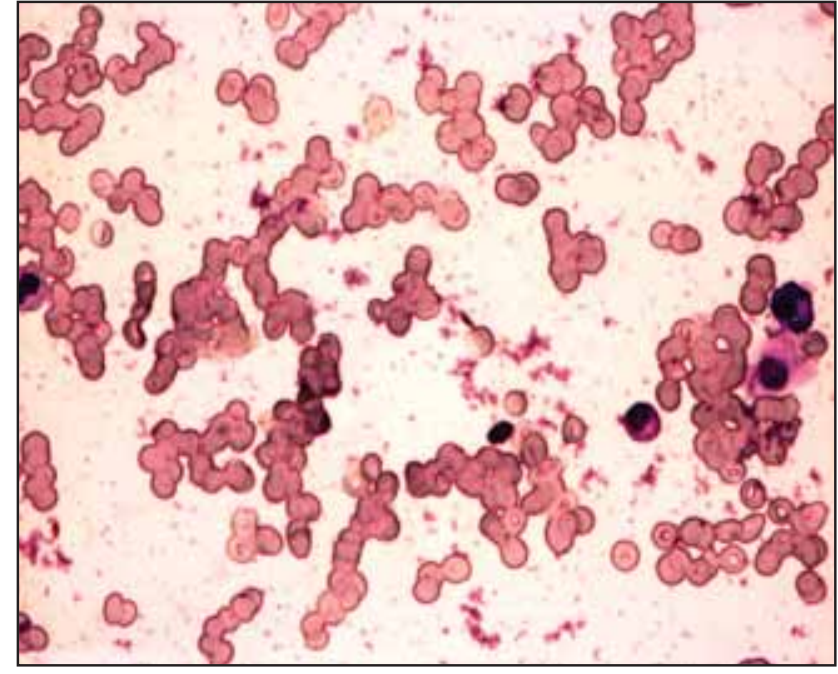

FIGURA 1. Hipocelularitate a măduvei osoase

Pe baza investigațiilor clinice şi paraclinice, s-a precizat diagnosticul pozitiv de anemie aplastică idiopatică, formă severă. S-au inițiat măsuri de terapie intensivă imediată, simptomatice şi tratament profilactic antibiotic cu cefalosporină din cauza neutropeniei severe şi riscului crescut de infecții oportuniste. Părinții au fost informați despre diagnosticul, metodele de tratament şi prognosticul bolii. S-a accentuat importanța testelor de histocompatibilitate în vederea unui transplant medular allogenic de la unul dintre fraţi şi s-a discutat cu un centru de transplant pediatric din țară în vederea preluării cazului. Mama a refuzat completarea investigațiilor şi continuarea tratamentului substitutiv în ciuda explicaţiilor medicului curant, şi a decis externarea copilului pe propria răspundere la 7 zile de la internare. 8 zile mai târziu, a prezentat din nou sângerări la nivelul cavităţii bucale, melenă şi hematurie, motiv pentru care este a fost reinternat de urgență cu anemie severă având Hemoglobină: 7,7 g/dL, Hematocrit: 27,6\%, trombocitopenie severă cu trombocite: $10.000 / \mathrm{uL}$, Leucocite: $1.300 /$ $\mathrm{uL}$; examenul de urină cu hematurie microscopică. S-au administrat preparate de sânge şi factori de stimulare hematopoietici până la stabilizarea pacientului; s-a discutat din nou cu aparținătorii opțiunile de tratament şi investigațiile care se impuneau a fi efectuate, însă refuzul mamei a împiedicat orice intervenţie în acest sens; s-a sesizat în mod repetat Direcția de Protecție a copilului. S-a instituit tratament cu Medrol, Ciclosporină şi adjuvante, cu răspuns terapeutic foarte lent. În următoarele săptămâni, pacientul a revenit de mai multe ori în stare gravă, însă de cele mai multe ori a fost externat la cererea mamei, fără a se reuşi stabilizarea totală a acestuia. La ultima internare a fost externat la cererea mamei cu hemoglobină de 
8,3 g/dL, Hematocrit de 23,1\%; Număr reticulocite: 0\%, Leucocite: 1,17/uL, cu Limfocite: 0,89/uL, Neutrofile: 0, Monocite: 0,02/uL, Bazofile: 0,03/ uL, PLT: 50.000/uL. 3 zile mai târziu, pacientul a revenit în serviciul de Urgență în stare generală gravă, somnolent, cu sindrom hemoragipar şi a decedat la scurt timp cu stop cardiorespirator, neresponsiv la manevrele de resuscitare. Ultimele investigații paraclinice din ziua decesului au arătat o insuficiență hepato-renală şi pancitopenie severă.

\section{DISCUȚII}

Anemia aplastică severă este definită ca fiind o pancitopenie severă îndeplinind cel puțin două din următoarele criterii: număr absolut de neutrofile $<500 / \mathrm{mm}^{3}$, număr de trombocite $<20.000 / \mathrm{mm}^{3}$ şi număr de reticulocite $<1 \%$ în prezența unei celularități reduse în măduvă $<25 \%$ (1). Rata de deces la 2 ani pentru pacienții cu forme severe de anemie aplastică tratați doar cu tratament suportiv este de aproximativ $80 \%$ (12), cele mai frecvente cauze de deces fiind sepsisul sever bacterian sau infecțiile fungice invazive (13).

În acest caz anemia aplastică a fost etichetată ca fiind idiopatică; investigațiile efectuate nu au putut pune în evidență un factor etiologic. Din cauza lipsei de complianță a părinților nu s-au putut efectua dozarea vitaminei $\mathrm{B}_{12}$ şi a folaţilor, dozarea hemoglobinei fetale, biopsia osteomedulară, un examen genetic cu cariotip, radiografie scheletală. Pe baza absenței anomaliilor tegumentare, scheletale şi la nivel unghial la pacientul nostru, precum şi a analizelor de laborator, am exclus o formă de anemie aplastică congenitală.

Prima linie de tratament în anemia aplastică este transplantul de măduvă, cu o rată de supraviețuire la 5 ani de 70-80\% (14). Tratamentul suportiv şi cel imunosupresiv sunt o alternativă de tratament pentru a preveni sângerările şi simptomatologia anemiei, dar trebuie pus în balanță raportul dintre riscul de a dezvolta anticorpi anti-HLA sau o hemocromatoză şi beneficiul dobândit pe termen scurt. $(15,16)$.

Având în vedere forma severă de anemie aplastică şi evoluția fulminantă, pacientul prezentat avea indicație majoră de transplant medular allogenic, mai ales pentru că avea şi doi frați sănătoşi; însă refuzul repetat al părinților de a efectua testele de histocompatibilitate, ne-au determinat să administrăm terapie imunosupresivă care s-a dovedit a fi ineficientă, pacientul decedând la câteva săptămâni de la iniţierea acesteia. Lipsa de complianță a familiei ne-a creat mari dificultăți privind conduita terapeutică şi justețea administrării tratamentului la domiciliu. În ceea ce priveşte sesizările repetate făcute către Protecția Copilului, am fi avut nevoie de un sprijin mai consistent cu privire la consilierea părinților asupra necesității de urgență a transplantului. Subliniem aici nevoia impunătoare a existenței unei legislații protective asupra minorilor cu patologii potențial fatale, care să oblige aparținătorii să fie participanți activi la orice tip de tratament care este în beneficiul copilului, cu precădere în cazurile în care se poate face diferența între viaţă şi moarte. Etica şi deontologia medicală sunt o parte extrem de importantă în pediatria hemato-oncologică; reprezintă de fapt promotorul acestei lupte cu sistemul - atunci când nu se are în vedere beneficiul copilului, sau uneori, precum în cazul de față, chiar cu aparținătorii, atunci când se încalcă un drept constituțional fundamental al copilului dreptul la viață, chiar de către cei care ar fi trebuit să îl apere în pofida oricărui impediment.

\section{CONCLUZII}

Cazul prezentat se încadrează într-o formă severă de anemie aplastică, având toate criteriile descrise mai sus. Evoluția fulminantă şi decesul unui copil de 9 ani, aparent sănătos, în mai puțin de 5 săptămâni de la debut, susțin particularitatea acestui caz. Prognosticul slab a fost influențat decisiv de lipsa de complianță a părinţilor, deoarece, în ciuda tratamentului imunosupresor şi substitutiv administrat, starea copilului s-a agravat progresiv. Este extrem de importantă aderența familiei la actul medical, dar şi implicarea mai activă şi mai promptă a Organizației de Protecție a Copilului cu privire la astfel de cazuri şi probabil introducerea unei legislații protectoare în acest sens. 